\title{
Viability and cell cycle of Melanoxylon brauna seeds submitted to drying and imbibition ${ }^{1}$
}

\author{
Mirian de Sousa Silva ${ }^{2}$, Carlos Roberto Carvalho ${ }^{3}$, \\ Eduardo Euclydes de Lima e Borges ${ }^{4 *}$, José Márcio Rocha Faria ${ }^{2}$
}

\begin{abstract}
The aim of this work was to evaluate viability and DNA ploidy of seed of Melanoxylon brauna submitted or not to fast drying, along soaking. The seeds were dried followed by germination and quantification of DNA ploidy pattern. There was a gradual decrease in germination percentage with increases in temperature and drying time. The DNA ploidy of embryonic axes that were not submitted to artificial drying indicated the existence of nuclei $2 \mathrm{C}, 4 \mathrm{C}$ and $8 \mathrm{C}$. However, $95 \%$ of the tested embrios had 2C DNA ploidy. The seeds that were subjected to rapid drying also exhibited the presence of nuclei $2 \mathrm{C}, 4 \mathrm{C}$ and $8 \mathrm{C}$ and showed no significant differences $(\mathrm{p}>0.05)$ compared to seeds that have not passed through drying. It is conclude that the seeds of Melanoxylon brauna submitted to different drying times and temperatures show a gradual decrease in the percentage of germination; embryonic axes subject or not to drying seeds have $2 \mathrm{C}, 4 \mathrm{C}$ and $8 \mathrm{C}$ nuclei and drying does not affect the cell cycle of cells in the embryo of the seed.
\end{abstract}

Index terms: ploidy, flow cytometry, drying.

\section{Viabilidade e ciclo celular de sementes de Melanoxylon brauna submetidas à secagem e embebição}

\begin{abstract}
RESUMO - Objetivou-se com este trabalho avaliar a viabilidade e a ploidia de DNA de sementes de Melanoxylon brauna, submetidas ou não à secagem rápida, ao longo da embebição. As sementes foram submetidas à secagem seguida por teste de germinação e quantificação da ploidia do DNA. Verificou-se decréscimo gradual na porcentagem de germinação com aumentos na temperatura e no tempo de secagem. A ploidia de DNA dos eixos embrionários que não foram submetidas à secagem artificial indicou a existência de núcleos 2C, 4C e 8C. No entanto, 95\% dos núcleos testados apresentaram ploidia de DNA 2C. As sementes que foram submetidas à secagem rápida também exibiram a presença de núcleos $2 \mathrm{C}, 4 \mathrm{C}$ e $8 \mathrm{C}$ e não apresentaram diferenças significativas ( $\mathrm{p}>0,05)$ em comparação com sementes que não passaram pela secagem. Conclui-se que as sementes de Melanoxylon brauna submetidas à secagem por diferentes tempos e temperaturas apresentam decréscimo gradual na porcentagem de germinação; eixos embrionários das sementes submetidas ou não à secagem apresentam núcleos 2C, 4C e 8C e a secagem não afeta o ciclo celular das células de embrião das sementes.
\end{abstract}

Termos para indexação: ploidia, citometria de fluxo, secagem.

\section{Introduction}

Melanoxylon brauna (brauna) belongs to the Fabaceae family and Caesalpinioideae subfamily, native in Brazil, is found mainly in the south of Bahia, São Paulo and Minas Gerais, in the Atlantic rain forest. The species reaches 15 to 25 $\mathrm{m}$ high, and its fruit is a dehiscent vegetable containing several seeds surrounded by a membranous structure, which makes possible its wind dispersal. Among the Brazilian woods, its is known as one of the toughest and incorruptible, being used in

${ }^{1}$ Submitted on 10/16/2013. Accepted for publication on 05/19/2014.

${ }^{2}$ Departamento de Ciências Florestais, UFLA, Caixa Postal 3037, 35540-000 -

Lavras, MG, Brasil. external works and hydraulic, for fence posts, poles, sleepers, bridges, building constructions and manufacturing of musical instruments. Currently, according to IBAMA Administrative Act 37/92, this specie is on the Official List of threatened species in the vulnerable category (IBAMA, 2013).

The ex situ conservation, i.e., outside the natural range of the relevant species as in seed banks, is a viable alternative for the conservation of genetic resources of species (Brow and Hardner, 2000). However, the lack of knowledge about the ideal conditions for drying and storage capacity for the

${ }^{3}$ Departamento de Biologia Geral, UFV, 36570-000 - Viçosa, MG, Brasil. ${ }^{4}$ Departamento de Engenharia Florestal, UFV, 36570-000 - Viçosa, MG, Brasil. *Corresponding author <elborges@ufv.br> 
native forest species has been an obstacle to the success of programs of germplasm banks over the long term, since not all seeds have the same behavior in regard to drying and storage (Davide et al., 2003; Jetton et al., 2008).

It is therefore essential that we determine the proper temperature for drying, as well as the exposure time at temperature to avoid damage and consequent loss of seeds quality, regardless of the level of desiccation tolerance. As an example, we have the Euterpe edulis seeds whose vigor was impaired by partial drying, showing different behavior depending on the harvest season (Martins et al., 2009). The same behavior was observed with seeds of Jatropha curcas by Zonta et al. (2011) the vigor of which was reduced at $43{ }^{\circ} \mathrm{C}$. However, the drying of Passiflora edulis at temperature of 30,35 and $40{ }^{\circ} \mathrm{C}$ did not affect the quality of the seeds (Carlesso et al., 2008).

The cell cycle, a process in which happens DNA synthesis and cell division has been indicated as a marker for the determination of possible changes in the seed physiological state during its development, maturation, drying and germination (Sliwinska, 2009). In the cell cycle, 2C nuclear DNA content in cells is found in the pre-synthesis $\left(\mathrm{G}_{1}\right)$ and 4C, in cells in which DNA replication has already happened $\left(G_{2}\right)$. The constant $C$ denotes the DNA content for haploid condition. Some researches indicate that cells in $G_{1}$ phase (2C) of cell cycle are more resistant to stress and have greater longevity than cells in the $\mathrm{G}_{2}$ phase (4C) (Saracco et al., 1995). However, the low water content during seed maturation could result in the nuclei accumulation in the G1 phase of cell cycle. The imbibition of the orthodox seed germination reactivate the mitotic cycle (Kozeko and Troyan, 2000).

In order to contribute to the knowledge about this specie, it was aimed to evaluate the viability and the DNA ploidy of Melanoxylon brauna seeds along the imbibition submitted or not to fast drying.

\section{Material and Methods}

Melanoxylon brauna seeds were obtained from fruits of four trees, located in a pasture area in the city of Leopoldina, Minas Gerais, where the climate is classified as tropical humid (Aw), with dry winter and summer rainy and average annual temperature of $21^{\circ} \mathrm{C}$ (Köppen, 1948). The fruits were collected in September 2008. After drying at room temperature for their complete dehiscence, seeds were manually selected - eliminating those immature, spoiled or damaged. The water content was then determined by the oven official method at a temperature of $105{ }^{\circ} \mathrm{C} \pm 3{ }^{\circ} \mathrm{C}$ for $24 \mathrm{~h}$ (Brasil, 2009), using three replicates of 20 seeds - and then stored in plastic bags placed in cardboard containers in a cold chamber $\left(60 \% \mathrm{RH}\right.$ at $\left.5{ }^{\circ} \mathrm{C}\right)$ for one month.
The seeds were taken randomly from the original batch and subjected to drying in an oven of circulation and air renewal, at temperatures of $40,50,60,70$ and $80{ }^{\circ} \mathrm{C}$ for 24,48 and $72 \mathrm{~h}$ and then subjected to the germination test, according to Corte et al. (2010), as described following: seeds were immersed in solution of Captan, $0,7 \%(\mathrm{p} / \mathrm{v})$ for $5 \mathrm{~min}$ and distributed in Petri dishes covered with two sheets of paper and moistened with $4,0 \mathrm{~mL}$ of + water and placed in a germination chamber at $25{ }^{\circ} \mathrm{C}$ and constant light (four fluorescent lamps, daylight type, $20 \mathrm{~W}$ ). The germination was monitored daily and radicle protrusion, defined as the criterion for germination. It was used five replicates of 20 seeds. Based on preliminares tests, which showed reductions in the percentage of germination and water content at $50{ }^{\circ} \mathrm{C}$ for 24 hours, but whose values were greater than at higher temperatures, the seeds were dried under those conditions and subjected to treatments shown in Table 1.

Table 1. Treatments applied to the analysis of flow cytometry, from the embryonic axis of Melanoxylon brauna seeds.

\begin{tabular}{|c|c|}
\hline Treatments & Sample \\
\hline 1 & Seeds maintained at $25^{\circ} \mathrm{C}$ for $96 \mathrm{~h}$ (Control) \\
\hline 2 & Seeds soaked at $25^{\circ} \mathrm{C}$ for $96 \mathrm{~h}$ \\
\hline 3 & $\begin{array}{l}\text { Dry seeds at } 50^{\circ} \mathrm{C} \text { for } 24 \mathrm{~h} \text { and maintained at } \\
25^{\circ} \mathrm{C} \text { for } 96 \mathrm{~h}\end{array}$ \\
\hline 4 & $\begin{array}{l}\text { Seeds dried at } 50^{\circ} \mathrm{C} \text { for } 24 \mathrm{~h} \text { and soaked at } \\
25^{\circ} \mathrm{C} \text { for } 96 \mathrm{~h}\end{array}$ \\
\hline 5 & Seeds maintained at $25^{\circ} \mathrm{C}$ for $132 \mathrm{~h}$ (Control) \\
\hline 6 & $\begin{array}{l}\text { Dry seeds at } 50{ }^{\circ} \mathrm{C} \text { for } 24 \mathrm{~h} \text { and maintained at } \\
25^{\circ} \mathrm{C} \text { for } 132 \mathrm{~h}\end{array}$ \\
\hline 7 & $\begin{array}{l}\text { Seeds dried at } 50^{\circ} \mathrm{C} \text { for } 24 \mathrm{~h} \text { and soaked at } \\
25^{\circ} \mathrm{C} \text { for } 132 \mathrm{~h}\end{array}$ \\
\hline 8 & Seeds maintained at $25^{\circ} \mathrm{C}$ for $168 \mathrm{~h}$ (Control) \\
\hline 9 & $\begin{array}{l}\text { Dry seeds at } 50{ }^{\circ} \mathrm{C} \text { for } 24 \mathrm{~h} \text { and maintained at } \\
25^{\circ} \mathrm{C} \text { for } 168 \mathrm{~h}\end{array}$ \\
\hline 10 & $\begin{array}{l}\text { Seeds dried at } 50^{\circ} \mathrm{C} \text { for } 24 \mathrm{~h} \text { and soaked at } \\
25^{\circ} \mathrm{C} \text { for } 168 \mathrm{~h}\end{array}$ \\
\hline
\end{tabular}

Seed maintained at $25^{\circ} \mathrm{C}$ for 96,132 and $168 \mathrm{~h}$ were used as control. For analysis of the percentage of nuclei with DNA ploidy $(2 \mathrm{C}, 4 \mathrm{C}, 8 \mathrm{C}$, etc.) within the cell cycle, embryonic axes were removed manually with the aid of pliers from each time. Then samples were frozen in liquid nitrogen and kept in microtubes, properly identified at $-20{ }^{\circ} \mathrm{C}$ until the date of the analysis. The samples were taken to the Laboratory of Plant Cytogenetics and Cytometry, Department of General Biology, Federal University of Viçosa, for preparation of suspensions of intact nuclei, according to the methodology proposed by Carvalho et al. (2008), and for subsequent analysis in the flow cytometer Partec PAS II/III (Partec Gmbh, Munster, Germany). For analysis of the nucleus stained with DAPI, it 
was used a mercury lamp of high pressure (HBO-100 W) with filters KG 1, BG 38 and GG 435. Each nuclear suspension was processed in the cytometer with at least 5,000 nuclei. The samples had coefficients of variation less than $5 \%$ according test of Tukey. Each treatment consisted of three repetitions with three subsamples each one.

\section{Results and Discussion}

The germination of Melanoxylon brauna removed from the original batch and soaked in water under constant light and temperature of $25^{\circ} \mathrm{C}$ (control) began with the protrusion of the radicle, from $72 \mathrm{~h}$ of imbibition. In the period from 96 to $132 \mathrm{~h}$ of soaking, there was an increase in the germination from $20 \%$ to $70 \%$, which reached $95 \%$ after $168 \mathrm{~h}$ (Figure 1). The seeds that were exposed to treatment at different drying times and temperatures, showed a gradual decrease in the germination percentage (Figure 1). The drying temperature of $40^{\circ} \mathrm{C}$ for $24 \mathrm{~h}$ (Figure 1A), was enough to cause changes in the seeds physiological quality. A temperature elevation of drying has accelerated the drying rate and hence the loss of seed quality. The intensity of immediate damage of drying at higher temperatures varies with the species and the temperature. Seeds of Pisum sativum were sensitive to temperature higher than $40{ }^{\circ} \mathrm{C}$ (Siddique and Wright, 2003), while the ones of Jatropha curcas had the electrical conductivity increased at $60{ }^{\circ} \mathrm{C}$, but only at $70{ }^{\circ} \mathrm{C}$ the germination decreased (Ullmann et al., 2010). According to José et al. (2004), the tolerants lines of Zea mays seeds to high temperature had no significant differences in enzyme activity for shade-dried seeds or artificially dried seeds.

The seeds were dispersed with low water content (approximately 13\%), and loss of water accompanied the increase in temperature and drying time (Figure 2). The water loss was faster in the first 24 hours in all drying temperatures, mainly in the higher temperatures.

The reduction in water content to $10.5 \%$ and $7 \%$, respectively at temperatures of $40{ }^{\circ} \mathrm{C}$ and $50{ }^{\circ} \mathrm{C}$ within $24 \mathrm{~h}$ was enough to decrease the seeds physiological quality. However, those that showed the water content below $6 \%$, after submitted to drying, were those who had the final germination below $47 \%$. It should be noted that the water content at about $3.5 \%$ of the seeds that were dried at temperatures of 60 and $70{ }^{\circ} \mathrm{C}$ within $72 \mathrm{~h}$ was not enough for the loss of total viability of seeds. The drying at the temperature of $80^{\circ} \mathrm{C}$ caused the death of the seeds when they reached 2\% water content (Figure 1). This desiccation tolerance, present in the Melanoxylon brauna seeds submitted to drying at temperatures of $40,50,60$ and $70{ }^{\circ} \mathrm{C}$, cannot be attributed to a simple protection mechanism. On the contrary, seems to be a multifactorial phenomenon, in which each component is also critical, acting in synergy and controlled by the genome (Leprince et al., 1993). As example, results obtained by Rosa et al. (2005) indicated that the acquisition of tolerance of maize seeds to high temperature is associated with the enzyme catalase and the presence in greater amount of LEA proteins. On the other hand, according to Taveira et al. (2012), the activity of heat-resistant proteins and antioxidant enzymes varied according to the quality of the coffee subjected to temperatures of $60{ }^{\circ} \mathrm{C}$ or $60 / 40^{\circ} \mathrm{C}$.
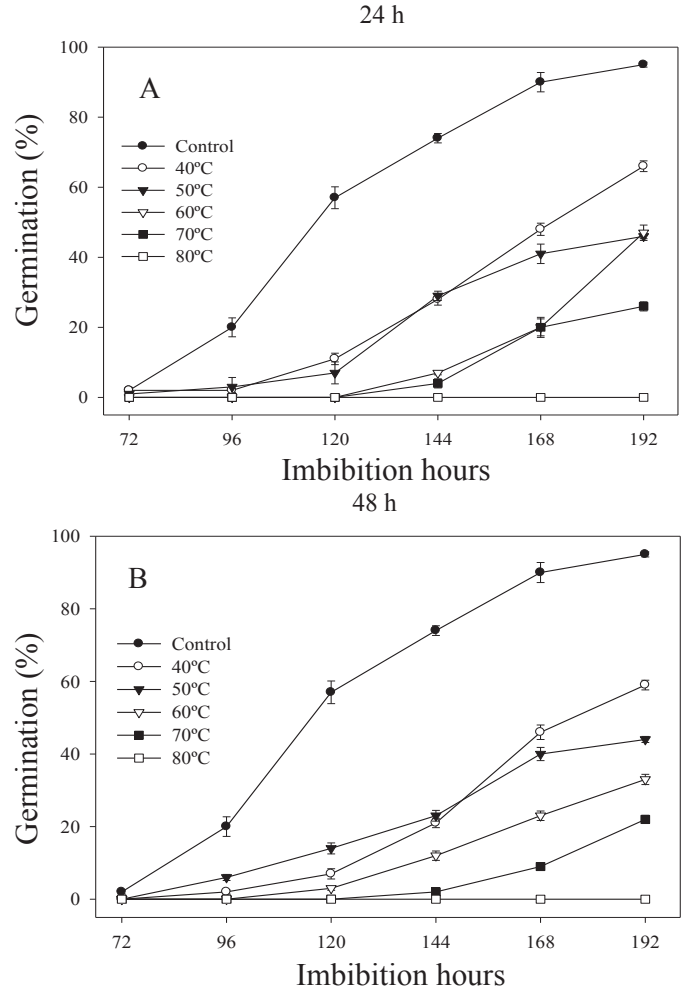

$72 \mathrm{~h}$

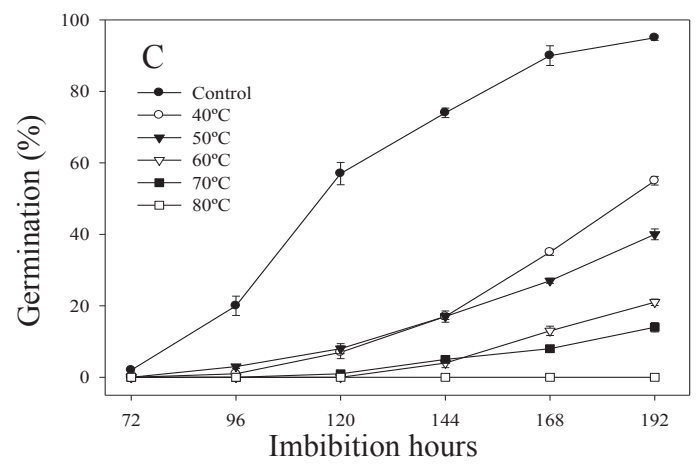

Figure 1. Germination of Melanoxylon brauna seeds submitted to drying in an oven for 24 (A), 48 (B) and $72(\mathrm{C})$ hours at temperatures of 40, 50, 60, 70 and $80^{\circ} \mathrm{C}$. Control (dry seeds at room temperature). Bar represents the standard deviation of the average. 


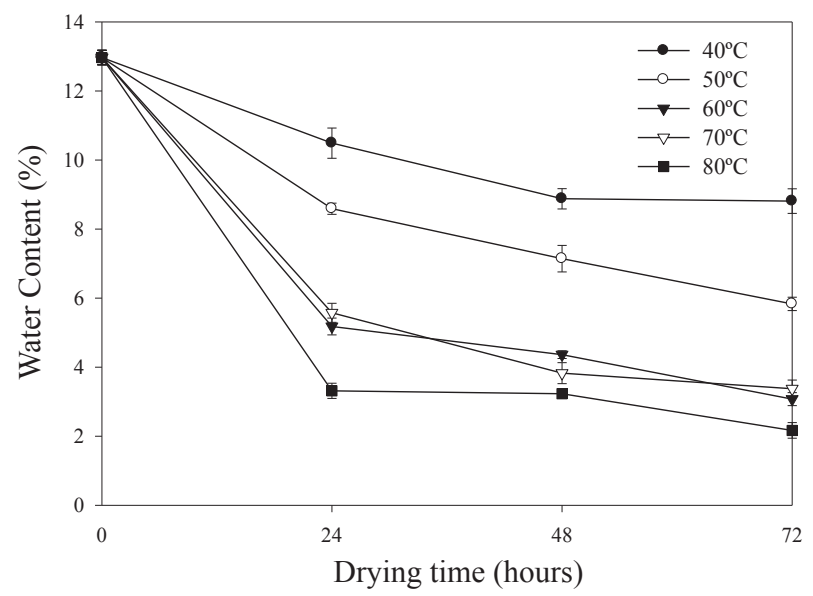

Figure 2. Changes in water content (\%) of Melanoxylon brauna seeds submitted to drying in an oven for 24,48 and $72 \mathrm{~h}$, at temperatures of $40,50,60,70$ and $80^{\circ} \mathrm{C}$. Bar represents the standard deviation of the average.

The evaluation of DNA ploidy by flow cytometry of embryonic axis of Melanoxylon brauna seeds, which were not subjected to artificial drying (controls), indicated the existence of nuclei 2C, 4C and 8C (Figure 3A). However, most of the cores tested showed the percentage of nuclei with 2C DNA ploidy (95\%), indicating that most cells were in the G1 phase of the cell cycle. The retention and accumulation of cells in G1 phase are related to the sharp decline in water content due to the drying, which occurs during maturation of orthodox seeds (Deltour, 1985).

The seeds submitted to fast drying in oven at $50{ }^{\circ} \mathrm{C}$ for 24 $\mathrm{h}$ and maintained at $25^{\circ} \mathrm{C}$ for 96 hours and then dried under the same conditions and soaked at $25^{\circ} \mathrm{C}$ for $96 \mathrm{~h}$ (treatments 3 and 4) also exhibited the presence of nuclei $2 \mathrm{C}, 4 \mathrm{C}$ and 8C (Figures 3C, D) and showed no significant differences $(p>0.05)$ the percentage of nuclei with DNA ploidy $2 \mathrm{C}, 4 \mathrm{C}$ and $8 \mathrm{C}$ compared to seeds that were not subjected to oven drying (Figure 4). These results demonstrate that there were no changes in DNA ploidy of embryonic axes of Melanoxylon brauna seeds among those subjected to natural and artificial drying at $50{ }^{\circ} \mathrm{C}$ for 24 hours. This indicates that the loss in the seeds germination capacity that were reduced in moisture content from $13 \%$ to $9 \%$ in fast drying in an oven at $50{ }^{\circ} \mathrm{C}$ for $24 \mathrm{~h}$ is not related to the activity of the cell cycle.

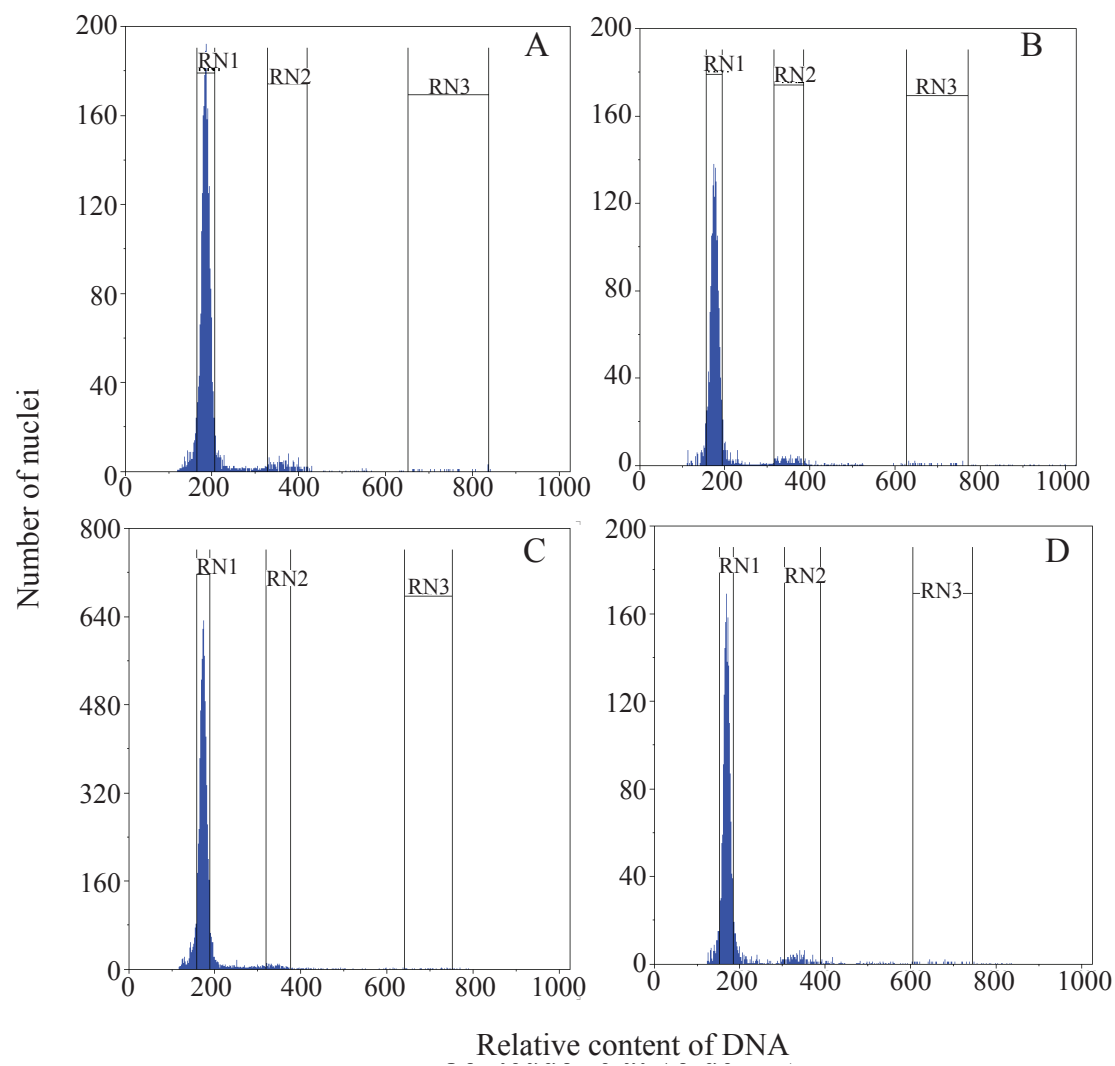

Figure 3. Histograms of flow cytometry analysis of nuclei of the embryonic axis of Melanoxylon brauna seeds. (A) Control, (B) Seeds soaked at $25^{\circ} \mathrm{C}$ for $96 \mathrm{~h},(\mathrm{C})$ Seeds dried at $50^{\circ} \mathrm{C}$ for $24 \mathrm{~h}$ and maintained at $25^{\circ} \mathrm{C}$ for $96 \mathrm{~h},(\mathrm{D})$ Seeds dried at $50{ }^{\circ} \mathrm{C}$ for $24 \mathrm{~h}$ and soaked at $25^{\circ} \mathrm{C}$ for $96 \mathrm{~h} . \mathrm{RN} 1=(2 \mathrm{C}) ; \mathrm{RN} 2=(4 \mathrm{C})$; and $\mathrm{RN} 3=(8 \mathrm{C})$ 
The Melanoxylon brauna seeds maintained at $25{ }^{\circ} \mathrm{C}$ for 132 and $168 \mathrm{~h}$ (treatments 5 and 8), those subject to fast drying in an oven at $50^{\circ} \mathrm{C}$ for $24 \mathrm{~h}$ and maintained to $25^{\circ} \mathrm{C}$ for 132 and $168 \mathrm{~h}$ (Treatments 6 and 9) and those that were dried at $50^{\circ} \mathrm{C}$ for $24 \mathrm{~h}$ and maintained at $25^{\circ} \mathrm{C}$ for 132 and $168 \mathrm{~h}$ (treatments 7 and 10) also exhibited the presence of nuclei $2 \mathrm{C}, 4 \mathrm{C}$ and $8 \mathrm{C}$ in the embryonic axes, and most nuclei showed the percentage of nuclei with 2C DNA ploidy (Figures 5 and 6). This is in accordance with the behavior of others species, like Acer

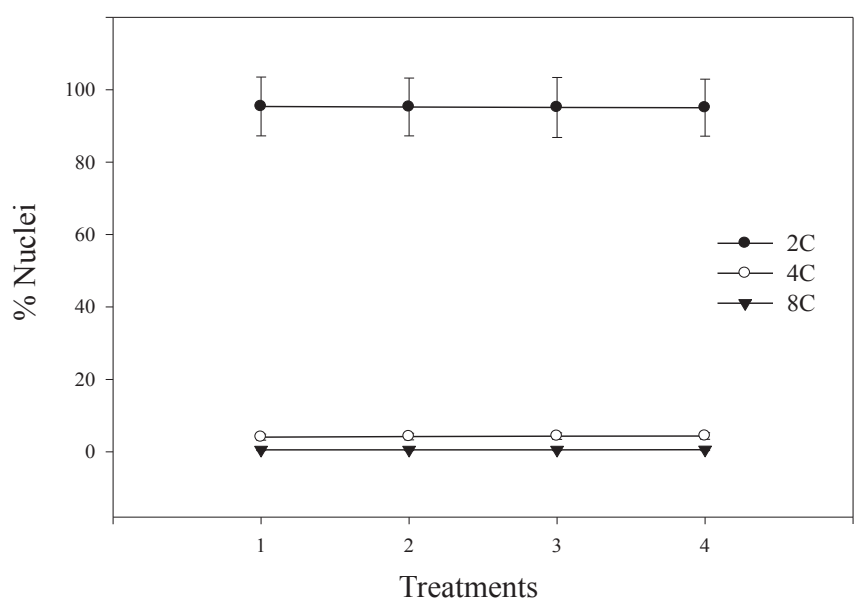

Figure 4. Average of the percentage of nuclei $2 \mathrm{C}, 4 \mathrm{C}$ and $8 \mathrm{C}$. 1- Control. 2 - Seeds soaked at $25{ }^{\circ} \mathrm{C}$ for $96 \mathrm{~h}$. 3Dry seeds at $50{ }^{\circ} \mathrm{C}$ for $24 \mathrm{~h}$ and maintained at $25^{\circ} \mathrm{C}$ for $96 \mathrm{~h} 4$ - Seeds dried at $50^{\circ} \mathrm{C}$ for $24 \mathrm{~h}$ and soaked at $25{ }^{\circ} \mathrm{C}$ for $96 \mathrm{~h}$. The bars represent the standard deviation. The average between treatments did not differ statistically by Tukey test at $5 \%$ probability.

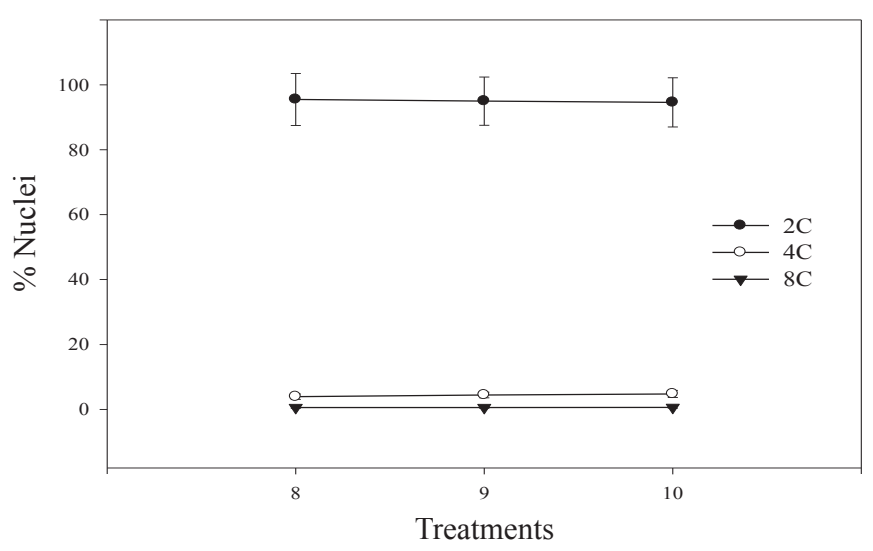

Figure 6. Average of percentage of nuclei $2 \mathrm{C}, 4 \mathrm{C}$ and $8 \mathrm{C}$. 8- Control. 9- Dry seeds at $50{ }^{\circ} \mathrm{C}$ for $24 \mathrm{~h}$ and maintained at $25{ }^{\circ} \mathrm{C}$ for $168 \mathrm{~h} 10$ - Seeds dried at $50{ }^{\circ} \mathrm{C}$ for $24 \mathrm{~h}$ and soaked at $25^{\circ} \mathrm{C}$ for $168 \mathrm{~h}$. The average between treatments did not differ statistically by Tukey test at $5 \%$ probability. saccharinum (Kozeko and Troyan, 2000), Coffea arabica (Silva et al., 2008) and Inga vera (Faria et al., 2004) that also showed the presence of high percentage of $2 \mathrm{C}$ nuclei in mature and dry seeds, indicating that its looks like a common behavior of different species during the beginning of germination process.

The presence of high percentage of $2 \mathrm{C}$ nuclei in mature and dry seeds has been observed at the beginning of the germination for Acer saccharinum (Kozeko and Troyan, 2000), Coffea arabica (Silva et al., 2008) and Inga vera (Faria et al., 2004).

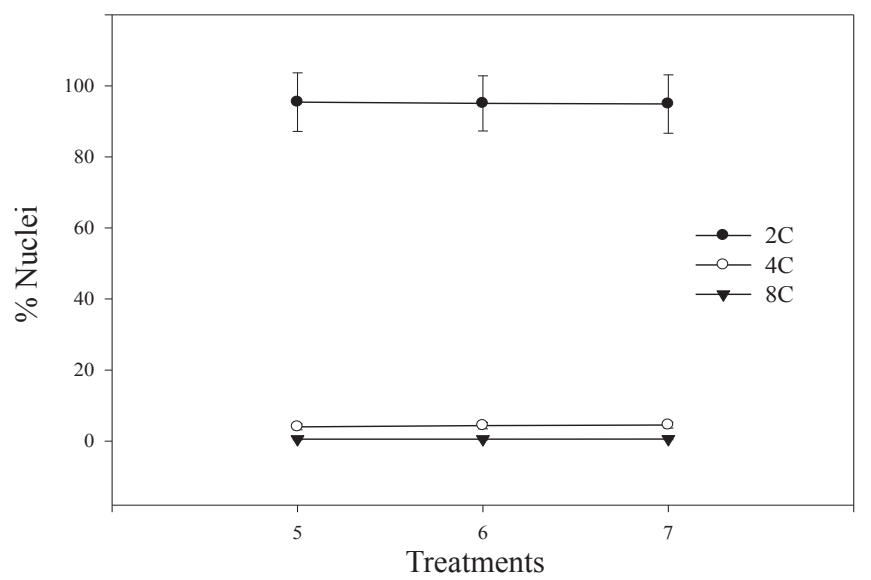

Figure 5. Average of percentage of nuclei $2 \mathrm{C}, 4 \mathrm{C}$ and $8 \mathrm{C}$. 5- Control. 6- Dry seeds at $50{ }^{\circ} \mathrm{C}$ for $24 \mathrm{~h}$ and maintained at $25{ }^{\circ} \mathrm{C}$ for $132 \mathrm{~h} 7$ - Seeds dried at $50{ }^{\circ} \mathrm{C}$ for $24 \mathrm{~h}$ and soaked at $25{ }^{\circ} \mathrm{C}$ for $132 \mathrm{~h}$. The average between treatments did not differ statistically by Tukey test at $5 \%$ probability.

\section{Conclusions}

Melanoxylon brauna seeds submitted to drying in an oven at different times and temperatures show a gradual decrease in the germination percentage.

The embryonic axis of Melanoxylon brauna seeds submitted or not to artificial drying in an oven, have nuclei $2 \mathrm{C}, 4 \mathrm{C}$ and $8 \mathrm{C}$.

Drying does not affect the cell cycle of cells in the embryo of Melanoxylon brauna seeds.

\section{Acknowledgements}

The authors acknowledge the researcher Marcos Deon Vilela de Resende for the help in flow cytometry data analysis; to $\mathrm{CNPq}$ for the grant of scholarships and to FAPEMIG for financial support. 


\section{References}

BRASIL. Ministério da Agricultura, Pecuária e Abastecimento. Regras para análise de sementes. Ministério da Agricultura, Pecuária e Abastecimento. Secretaria de Defesa Agropecuária. Brasília: MAPA/ACS, 2009. 395p. http:// www.bs.cca.ufsc.br/publicacoes/regras\%20analise $\% 20$ sementes.pdf

BROWN, A.H.D.; HARDNER, C.M. Sampling the gene pools of forest trees for ex situ conservation. In: YOUNG, A.; BOSHIER, D.; BOYLE, T. (Ed.). Forest Conservation Genetics: principles and practice. Coolingwood: Publishing, 2000. p.185-196.

CARLESSO, V.O.; BERBERT, P.A.; SILVA, R.F.; DETMANN, E. Secagem e armazenamento de sementes de maracujá amarelo (Passiflora edulis Sims f. Alavicarpa Degener). Revista Brasileira de Sementes, v.30, n.2, p. 65-74, 2008. http://www.scielo.br/pdf/rbs/v30n2/a09v30n2.pdf

CARVALHO, C. R.; CLARINDO, W. R.; PRAÇA, M. M., ARAÚJO, F. S.; CARELS, N. Genome size, base composition and karyotype of Jatropha curcas L.: an important biofuel plant. Plant Science, v.174, n.6, p.613-617, 2008. http://www.sciencedirect.com/science/article/pii/S0168945208000745

CORTE, V.B.; BORGES, E.E.L.; LEITE, H.G.; PEREIRA, B.L.P.; GONÇALVES, J.F.C. Estudo enzimático da deterioração de sêmenes de Melanoxylon brauna submetidas ao envelhecimento natural e acelerado. Revista Brasileira de Sementes, v.32, n.1, p.83-91, 2010. http://dx.doi. org/10.1590/S0101-31222010000100010

DAVIDE, A. C.; CARVALHO, L. R.; CARVALHO, M. L. M.; GUIMARAES, R. M. Classificação fisiológica de sementes de espécies florestais pertencentes à família Lauraceae quanto à capacidade de armazenamento. Cerne, v.9, n.1, p. 29-35, 2003. http://www.dcf.ufla.br/cerne/administracao/publicacoes/ m203v9n1o3.pdf.

DELTOUR, R. Nuclear activation during early germination of the higher plant embryo. Journal Cell Science, v.75, p.43-83, 1985.

FARIA, J. M. R.; LAMMEREN, A. A. M. VAN; HILHORST, H.W.M. Desiccation sensitivity and cell cycle aspects in seeds of Inga vera subsp. affinis. Seed Science Research, v.14, p.165-178, 2004. http://dx.doi. org/10.1079/SSR2004166

IBAMA. Instituto Brasileiro do Meio Ambiente e dos Recursos Naturais Renováveis. Lista Oficial de Flora Ameaçada de extinção. Portaria nº. 37-N de 3 de abril,1992. Disponível em: http://www.ibama.gov.br/flora/extincao. htm. Accessed on: Jun. 26 $6^{\text {th }} .2013$.

JETTON, R. M.; DVORAK, W. H.; WHITTIER, W.A. Ecological and genetic factors that define the natural distribution of Carolina hemlock in the southeastern United States and their role in situ conservation. Forest Ecology and Management, v.255, n.8-9, p.3212-3221, 2008. http://www. sciencedirect.com/science/article/pii/S0378112708000777

JOSÉ, S.C.B.R.; VON PINHO, E.V.R.; VON PINHO, R.G.; SILVEIRA, C.M. Padrões eletroforéticos da enzima $\alpha$-amilase em sementes de milho submetidas a alta temperatura de secagem. Revista Brasileira de Sementes, v.26, n.1, p.77-83, 2004. http://dx.doi.org/10.1590/S010131222004000100012
KÖPPEN, W. Climatologia. Buenos Aires: Panamericana, 1948. 478p.

KOZEKO, L. E.; TROYAN, V. M. The relationship between the mitotic activity and moisture content of recalcitrant seeds of Acer saccharinum (L.) during maturation, post maturation drying and germination. Seed Science Research, v.10, p.225-232, 2000. http://dx.doi.org/10.1017/ S0960258500000258

LEPRINCE, O.; HENDRY, G. A. F.; MCKERSIE, B. D. The mechanims of desiccation tolerance in developing seeds. Seed Science Research, v.3, p.231246, 1993. http://dx.doi.org/10.1017/S0960258500001859

MARTINS, C. C.; BOVI, M. L. A.; NAKAGAWA, J.; MACHADO, C. G. Secagem e armazenamento de sementes de juçara. Revista Árvore, v.33, n.4, p.635-642, 2009. http://dx.doi.org/10.1590/S0100-67622009000400006

ROSA, S.D.V.; VON PINHO, E.V.R.; VIEIRA, E.S.N.; REIGA, R.D.; VEIGA, A.D. Enzimas removedoras de radicais livres e proteínas LEAs associadas à tolerância de sementes de milho à alta temperatura de secagem. Revista Brasileira de Sementes, v.27, n.2, p.91-101, 2005. http://www.scielo. br/scielo.php?script=sci_arttext\&pid=S0101-31222005000200014

SARACCO, F.; BINO, R. J.; BERGERVOET, J. H. W.; LANTERI, S. Influence of priming-induced nuclear replication activity on storability of pepper (Capsicum annuum L.) seed. Seed Science Research, v.5, n.1, p. 25 29, 1995. http://dx.doi.org/10.1017/S0960258500002555

SIDDIQUE, A.B.; WRIGHT, D. Effects of different drying time and temperature on moisture percentage and seed quality (viability and vigour) of pea seeds (Pisum sativum L.). Asian Journal Plant Science, v.2, p.978-982, 2003. http://scialert.net/abstract/?doi=ajps.2003.978.982

SILVA, E. A. A.; TOOROP, P. E., LAMMEREN, A. A. M. van; HILHORST, H. W. M. ABA inhibits embryo cell expansion and early cell division events during coffee (Coffea arabica 'rubi') seed germination. Annals of Botany, v. 102, n.3, p. 425-433, 2008. http://www.ncbi.nlm.nih.gov/pmc/articles/PMC2701795/

SLIWINSKA, E. Nuclear DNA replication and seed quality. Seed Science Research, v.19, p.15-25, 2009. http://dx.doi.org/10.1017/S0960258508186275

TAVEIRA, J.H.S.; ROSA, S.D.V.F.; BORÉM, F.M.; GIOMO, G.S.; SAATH, R. Perfis proteicos e desempenho fisiológico de sementes de café submetidas a diferentes métodos de processamento e secagem. Pesquisa Agropecuária Brasileira, v.47, n.10, p.1511-1517, 2012. http://seer.sct.embrapa.br/index. php/pab/article/view/12086/8148

ULLMANN, R.; REZENDE, O.; SALES, J.F.; CHAVES, T.H. Qualidade das sementes de pinhão manso submetidas à secagem artificial. Revista Ciência Agronômica, v.41, n.3, p.442-447, 2010. www.ccarevista.ufc.br

ZONTA, J.B.; ARAUJO, E.F.; ARAUJO, R.F.; DIAS, L.A.S. Diferentes tipos de secagem: efeitos na qualidade fisiológica de sementes de pinhão-manso. Revista Brasileira de Sementes, v.33, n.4, p.724-734, 2011. http://www.alice. cnptia.embrapa.br/bitstream/doc/906656/1/secagemsementespinhaomanso.pdf 